УДК 30.341.1:621.3

DOI: https://doi.org/10.37320/2415-3583/9.12

Волощук В.P.

кандидат економічних наук, асистент кафедри фінансів, банківської справи, страхування та електронних платіжних систем, Подільський державний аграрно-технічний університет ORCID: https://orcid.org/0000-0003-0041-4134

Богачик C.B.

аспірант,

Подільський державний аграрно-технічний університет

\title{
МЕХАНІЗМИ ЗАБЕЗПЕЧЕННЯ ІННОВАЦІЙНОГО РОЗВИТКУ АГРОПРОМИСЛОВИХ ПІДПРИЕМСТВ
}

\begin{abstract}
Статтю присвячено розгляду та обгрунтуванню теоретичних аспектів формування механізму забезпечення інноваційного розвитку агропромислових підприємств. Аргументовано необхідність відтворення агропромислових підприємств иляхом інноваційного розвитку. Визначено складники та інструменти механізмів системи забезпечення інновачійного розвитку підприємств. Проведено аналіз стану фінансування та визначено напрями реалізації процесу інновачійного розвитку на основі даних Державної служби статистики за період 2010-2018 рр. Обтрунтовано необхідність упровадження механізмів забезпечення інновачійного розвитку агропромислових підприємств, таких як організаційно-інституційний, економічний, виробничо-технологічний, комериійно-збутовий та сочіально-мотиваційний. Окреслено інструменти забезпечення позитивної дії вказаних механізмів. Визначено, щцо використання вказаних механізмів дасть змогу набути додаткових конкурентних переваг підприємствам галузі АПК, залучити нові джерела інвестиційних ресурсів, забезпечити ефективне їх використання тощзо.
\end{abstract}

Ключові слова: інновації, розвиток, ресурси, агропромислові підприємства, фінансування, інвестиції.

Постановка проблеми. Агропромислові підприємства постійно перебувають у процесі пошуку інвестицій, що дадуть змогу забезпечити інноваційний розвиток, підвищити рівень конкурентоспроможності у ринковому середовищі. У вітчизняних підприємствах аграрної сфери ефективне використання механізмів та інструментів забезпечення інноваційного розвитку зумовлене особливостями в питаннях фінансових та інвестиційних можливостей, виробничого процесу, технологій, нормативно-правової бази, інтелектуальної власності, процесу їх реалізації, що потребує детальних досліджень у вказаному напрямі.

Аналіз досліджень і публікацій. Вивчення понять та ролі інновацій та інноваційного розвитку підприємств знайшло своє висвітлення у роботах таких вітчизняних та зарубіжних учених, як Й. Шумпетер [1] С. Ілляшенко [2], I. Вінніченко [3], В. Никифоренко [4], К. Волощук [5], А. Тофанчук [6], Ю. Шипуліна [7], С. Юріна [8], Д. Шевчук [9], О. Балан [10] та ін. Зокрема, у працях цих авторів розглядаються питання визначення сутності інновацій та інноваційної діяльності підприємств, інвестиційного забезпечення інноваційного розвитку, ризики та напрями їх подолання.

Однак значна кількість особливостей аграрної сфери, а також стратегічні напрями інвестиційно-інноваційної діяльності агропромислових підприємств стосовно інноваційного розвитку потребують більш детального опрацювання наяв- них та потенційних механізмів його забезпечення. Потрібним є врахування того, що інноваційний розвиток потребує значних обсягів фінансоворесурсного забезпечення. Після визначення оптимальних адекватних механізмів інноваційного розвитку підприємствам необхідно також упровадити їх через застосування відповідних інструментів у господарську практику.

Мета статті полягає у визначенні та обгрунтуванні механізмів й інструментів забезпечення інноваційного розвитку агропромислових підприємств.

Виклад основного матеріалу. На думку C.В. Юріна, сукупна потреба в ресурсах незалежно від їх наявності у підприємства $є$ ресурсним забезпеченням інноваційного розвитку. Він зазначає, що підприємство в процесі інноваційного розвитку повинне прагнути до постійного оновлення, накопичення відповідних ресурсів (забезпечення), що повинно змінювати та вдосконалювати існуючу сукупність уже накопиченого потенціалу [8].

Д.А. Шевчук виділяє такі процеси ресурсного забезпечення підприємства: визначення ресурсних потреб; мобілізація ресурсів (оцінка i закріплення джерел надходження капіталу); формування та виконання бюджету (грошових коштів, запасів, основних фондів, продажу продукції тощо) [9].

Погляди на ресурсне забезпечення інноваційного розвитку як на процес у працях різних 
дослідників є подібними. Переважно вчені виділяють етапи оцінки ресурсних потреб, визначення джерел надходження необхідних ресурсів і контролю над процесом їх використання.

Проте ресурсне забезпечення діяльності організації можна розглядати й як процес, що передбачає накопичення та розподіл ресурсів, планування, моніторинг, контроль, упровадження систем раціонального використання наявних ресурсів.

Для формування відповідного ресурсного потенціалу, його ефективного використання та подальшого інноваційного розвитку кожне підприємство повинне мати певні обсяги фінансових ресурсів. Нестача фінансових ресурсів вітчизняних призводить до виникнення заборгованостей, негативно впливає на їхні імідж та можливості. Джерелами фінансування аграрних підприємств можуть бути власні кошти, позикові джерела, державне цільове фінансування (табл. 1).

Так, основним джерелом фінансування інноваційної діяльності підприємств промисловості регіону залишаються власні кошти підприємств - 96\% у 2017 р., проте в 2010 р. вони становили лише $4,3 \%$ від загального фінансування. 32014 р. фінансування інноваційної діяльності промисловості регіону за рахунок іноземних інвестицій не спостерігається.

За дослідженнями О.Д. Балана [10], 75-80\% одержуваного сільгосппідприємствами прибутку доцільно спрямовувати на розширене відтворення i 20-25\% - на споживання. Такий підхід дасть змогу здійснювати інноваційне технологічне забезпечення засобами виробництва і застосовувати дієву систему матеріального стимулювання працівників. Динаміку капітальних інвестицій за видами економічної діяльності зведено у табл. 2.

Аналіз динаміки капітальних інвестицій за видами економічної діяльності на основі даних табл. 2 указує на те, що у 12 разів більше їх вкладено у сферу наукової та технічної діяльності, у 8,3 рази більше - у транспорт, складське господарство, поштову та кур'єрську діяльність, у 7,2 рази більше - у сільське, лісове та рибне господарство, а в цілому - у 3,5 рази. Менше капітальних інвестицій спрямовано у фінансову та страхову діяльність, тимчасове розміщування й організацію харчування, мистецтво, спорт, розваги та відпочинок.

Прямі інвестиції в Хмельницькій області за видами економічної діяльності зведемо в табл. 3. Недостатній рівень інвестування аграрного сектору зумовлений низькою привабливістю сільськогосподарського виробництва. Дані таблиці вказують на скорочення обсягів прямих інвестицій майже по всіх видах діяльності за винятком промисловості, будівництва, операцій із нерухомим майном.

Оскільки нині Україна та більшість ії регіонів і підприємств відчувають нестачу власних фінансових ресурсів, усе більшого значення набуває залучення іноземних інвестицій. Держава покликана створити іноземним інвесторам належне для їхньої діяльності в Україні економічне середовище через уведення державних гарантій реалізації найбільш ефективних проєктів; розроблення комплексної програми стимулювання вітчизняних та іноземних інвестицій в агропромислову сферу; визначення переліку пріоритетних галузей, виробництв та підприємств, яким надаватиметься пільговий режим оподаткування.

Тому держава повинна: забезпечити належну правову базу, що дасть змогу сформувати сприятливий інвестиційний клімат; створити належні умови для розроблення й упровадження і комерціалізації інновацій; побудувати відповідну систему інженерно-технічного забезпечення агропромислової галузі; збільшувати обсяги вкладень в основний капітал; забезпечити зниження кредитних ставок і збереження пільг щодо оподаткування підприємств галузі; сприяти залученню в агропромислову галузь прямих іноземних інвестицій тощо.

Для агропромислових підприємств, які планують упровадження інновацій, організаційноінституційний механізм має значне значення для мінімізації ризиків у процесі інвестування та

Таблиця 1 - Джерела фінансування інноваційної діяльності промислових підприсмств Хмельницької обл., тис грн

\begin{tabular}{|c|c|c|c|c|c|}
\hline \multirow{2}{*}{ Роки } & \multirow{2}{*}{$\begin{array}{c}\text { Загальна } \\
\text { сума витрат }\end{array}$} & \multicolumn{4}{|c|}{ У тому числі за рахунок коштів } \\
\cline { 3 - 6 } & & власних & $\begin{array}{c}\text { вітчизняних } \\
\text { інвесторів }\end{array}$ & $\begin{array}{c}\text { іноземних } \\
\text { інвесторів }\end{array}$ & інші джерела \\
\hline 2010 & 749588,2 & 31929,0 & - & 213992,0 & 501773,0 \\
\hline 2014 & 133121,2 & 76291,2 & - & - & 56830,0 \\
\hline 2015 & 66659,4 & 54952,0 & - & - & 11707,4 \\
\hline 2017 & 24552,5 & 23547,9 & - & - & 1004,6 \\
\hline $\begin{array}{c}\text { Відношення 2017 p. } \\
\text { до 2010 p., \% }\end{array}$ & 3,3 & 73,7 & - & - & 0,2 \\
\hline
\end{tabular}

*Періодичність проведення державного статистичного спостереження щодо інноваційної діяльності промислового підприємства змінена 3 «річної» на «один раз на два роки» починаючи з 2015 р.

Джерело: побудовано на основі даних Головного управління статистики у Хмельницькій області 
Таблиця 2 - Капітальні інвестиції за видами економічної діяльності, тис грн

\begin{tabular}{|c|c|c|c|c|c|c|c|}
\hline & 2010 p. & 2014 p. & 2015 p. & 2016 p. & 2017 p. & 2018 p. & $\begin{array}{c}\text { Відношення } \\
2018 \text { р. до } \\
2010 \text { р., \% } \\
\end{array}$ \\
\hline Усього & 2947584 & 4078277 & 6809321 & 9123259 & 10139119 & 10435246 & в $3,5 \mathrm{p}$. \\
\hline $\begin{array}{l}\text { Сільське, лісове та рибне } \\
\text { господарство }\end{array}$ & 443867 & 826537 & 1585237 & 1840500 & 2467214 & 3219993 & в 7,2 p. \\
\hline Промисловість & 1155444 & 924104 & 1169708 & 2064753 & 2564382 & 3465636 & в $3 \mathrm{p}$. \\
\hline Будівництво & 829048 & 852699 & 1516269 & 1158690 & 814989 & 883355 & 106,6 \\
\hline Оптова та роздрібна торгівля; & 93388 & 91366 & 149351 & 249882 & 284478 & 345387 & в $3,7 \mathrm{p}$. \\
\hline $\begin{array}{l}\text { Транспорт, складське } \\
\text { господарство, }\end{array}$ & 31920 & 110114 & 132603 & 234641 & 356797 & 266133 & в $8,3 \mathrm{p}$. \\
\hline $\begin{array}{l}\text { Тимчасове розміщування й } \\
\text { організація харчування }\end{array}$ & 4350 & 2853 & 5155 & 3862 & 5630 & 3354 & 77,1 \\
\hline Інформація та телекомунікації & 5013 & 4193 & 9885 & 7023 & 2470 & 9961 & 198,7 \\
\hline $\begin{array}{l}\text { Фінансова та страхова } \\
\text { діяльність }\end{array}$ & 593 & 149 & 211 & 191 & н/д & 205 & 34,6 \\
\hline Операції з нерухомим майном & 106525 & 150357 & 207691 & 188105 & 261921 & 235723 & в 2,2 p. \\
\hline Наукова та технічна діяльність & 5493 & 16253 & 20368 & 18739 & 23566 & 66106 & в $12 \mathrm{p}$. \\
\hline Державне управління й оборона & 165778 & 136586 & 269249 & 671797 & 820245 & 1118158 & в $6,7 \mathrm{p}$. \\
\hline Освіта & 24832 & 13719 & 45181 & 42902 & 46666 & 62275 & в $2,5 \mathrm{p}$. \\
\hline Охорона здоров’я & 39914 & 36139 & 113722 & 108007 & 157024 & 230285 & в 5,8 p. \\
\hline $\begin{array}{l}\text { Мистецтво, спорт, розваги та } \\
\text { відпочинок }\end{array}$ & 11310 & 1671 & 3010 & 5358 & 16728 & 7272 & 64,3 \\
\hline
\end{tabular}

Джерело: побудовано на основі даних Головного управління статистики у Хмельнищькій області

Таблиця 3 - Прямі інвестиції (акціонерний капітал) за видами економічної діяльності у Хмельницькій обл., тис дол. США

\begin{tabular}{|c|c|c|c|c|c|c|c|}
\hline & 2010 p. & 2014 p. & 2015 p. & 2016 p. & 2017 p. & 2018 p. & $\begin{array}{c}\text { Відношення } \\
2018 \text { р. до } \\
2010 \text { р., \% } \\
\end{array}$ \\
\hline Усього & 182975,1 & 189096,9 & 165530,0 & 158158,3 & 170764,1 & 199465,3 & 109,0 \\
\hline $\begin{array}{l}\text { Сільське, лісове та рибне } \\
\text { господарство }\end{array}$ & 9224,1 & 17423,5 & 10429,6 & 10059,0 & 10155,7 & 8010,6 & 86,8 \\
\hline Промисловість & 134903,4 & 136491,7 & 120352,5 & 114091,4 & 127314,0 & 157471,3 & 116,7 \\
\hline Будівництво & 204,6 & 1206,1 & 1107,6 & 1095,9 & 308,7 & 327,1 & 159,9 \\
\hline $\begin{array}{l}\text { Оптова та роздрібна торгівля; } \\
\text { ремонт автотранспортних } \\
\text { засобів і мотоциклів }\end{array}$ & 21452,3 & 22352,4 & 21933,9 & 21751,1 & 21569,7 & 21285,8 & 99,2 \\
\hline $\begin{array}{l}\text { Транспорт, складське } \\
\text { господарство, поштова та } \\
\text { кур’єрська діяльність }\end{array}$ & 2703,5 & 3222,8 & 2868,5 & 2563,6 & 1646,1 & 1594,9 & 59,0 \\
\hline Інформація та телекомунікації & 297,0 & 103,4 & 73,1 & 46,9 & 45,4 & 46,0 & 15,5 \\
\hline Операції з нерухомим майном & 7791,2 & 7882,0 & 7989,4 & 7847,3 & 9017,3 & 10411,4 & 133,6 \\
\hline $\begin{array}{l}\text { Професійна, наукова та } \\
\text { технічна діяльність }\end{array}$ & 3008,6 & 22,0 & 9,2 & $\ldots{ }^{1}$ & $\ldots{ }^{1}$ & $\ldots{ }^{1}$ & * \\
\hline $\begin{array}{l}\text { Діяльність у сфері } \\
\text { адміністративного та } \\
\text { допоміжного обслуговування }\end{array}$ & 3246,2 & 255,6 & 228,1 & 219,5 & 235,8 & 229,7 & 7,1 \\
\hline
\end{tabular}

1 Дані не оприлюднюються 3 метою забезпечення виконання вимог Закону України «Про державну статистику» щодо конфіденційності статистичної інформації.

Джерело: побудовано на основі даних Головного управління статистики у Хмельницькій області

впровадження. Ураховуючи, що результативність діяльності в аграрній сфері залежить від багатьох чинників, то результат інвестування в інноваційний розвиток доцільно порівнювати 3 рівнем обсягів виробництва, якості продукції, техноло- гій, обслуговування, управління персоналом, рівнем диверсифікації виробництва тощо (табл. 4).

Економічний механізм спрямовується на активізацію інноваційного розвитку стосовно джерела фінансових ресурсів під час формування ресурс- 
Таблиця 4 - Механізми та інструменти активізації інноваційного розвитку агропромислових підприємств

\begin{tabular}{|c|c|c|c|c|}
\hline $\begin{array}{c}\text { Організаційно- } \\
\text { інституційний } \\
\text { механізм }\end{array}$ & $\begin{array}{l}\text { Економічний } \\
\text { механізм }\end{array}$ & $\begin{array}{c}\text { Виробничо- } \\
\text { технологічний } \\
\text { механізм }\end{array}$ & $\begin{array}{c}\text { Комерційно- } \\
\text { збутовий механізм }\end{array}$ & $\begin{array}{c}\text { Соціально- } \\
\text { мотиваційний } \\
\text { механізм } \\
\end{array}$ \\
\hline $\begin{array}{l}\text { процеси, пов’язані } \\
3 \text { підготовкою, } \\
\text { ухваленням } \\
\text { та реалізацією } \\
\text { управлінських рішень } \\
\text { у всіх напрямах } \\
\text { діяльності }\end{array}$ & $\begin{array}{l}\text { формування } \\
\text { необхідного обсягу } \\
\text { фінансових ресурсів } \\
\text { із різних джерел } \\
\text { для активізації } \\
\text { інноваційно- } \\
\text { інвестиційної } \\
\text { діяльності }\end{array}$ & $\begin{array}{l}\text { використання } \\
\text { новітніх технологій, } \\
\text { модернізацію } \\
\text { матеріально- } \\
\text { технічної бази, } \\
\text { формування } \\
\text { ефективного } \\
\text { ресурсного } \\
\text { потенціалу }\end{array}$ & $\begin{array}{l}\text { розвиток } \\
\text { інформаційних } \\
\text { технологій, } \\
\text { інформаційно- } \\
\text { аналітичних засобів, } \\
\text { маркетингово- } \\
\text { логістичних, } \\
\text { техніко- } \\
\text { технологічних } \\
\text { систем }\end{array}$ & $\begin{array}{l}\text { розвиток } \\
\text { інтелектуально- } \\
\text { кадрового } \\
\text { потенціалу, } \\
\text { впровадження } \\
\text { інновацій із } \\
\text { найбільшим } \\
\text { соціальним } \\
\text { результатом }\end{array}$ \\
\hline \multicolumn{5}{|c|}{ Інструменти } \\
\hline $\begin{array}{l}\text {-удосконалення } \\
\text { правового } \\
\text { забезпечення } \\
\text { інвестиційно- } \\
\text { інноваційної } \\
\text { діяльності; } \\
\text { - стратегічне і } \\
\text { тактичне планування } \\
\text { інноваційної } \\
\text { діяльності та } \\
\text { підвищення їі } \\
\text { ефективності; } \\
\text { - створення } \\
\text { інформаційно- } \\
\text { аналітичного } \\
\text { центру активізації } \\
\text { інвестиційно- } \\
\text { інноваційної } \\
\text { діяльності; } \\
\text { - використання } \\
\text { «портфельного } \\
\text { підходу» до } \\
\text { бюджетування } \\
\text { інновацій; } \\
\text { - участь в } \\
\text { інноваційних } \\
\text { кластерах та } \\
\text { мережевих структурах }\end{array}$ & $\begin{array}{l}\text { - інвестування } \\
\text { коштів у розширення } \\
\text { і модернізацію } \\
\text { технологічного } \\
\text { процесу; } \\
\text { - активізація } \\
\text { інноваційної } \\
\text { діяльності; } \\
\text { - впровадження } \\
\text { альтернативних } \\
\text { джерел фінансування } \\
\text { реалізації } \\
\text { інноваційних } \\
\text { проєктів; } \\
\text { - активізація } \\
\text { використання та } \\
\text { оновлення активів } \\
\text { відповідно до } \\
\text { інноваційних цілей }\end{array}$ & $\begin{array}{l}\text { - розширення } \\
\text { асортименту } \\
\text { інноваційних } \\
\text { товарів; } \\
\text {-диверсифікація } \\
\text { виробничої } \\
\text { діяльності; } \\
\text { - проведення } \\
\text { модернізації } \\
\text { технологічного } \\
\text { процесу; } \\
\text { - розширене } \\
\text { відтворення та } \\
\text { технічне оновлення } \\
\text { матеріально- } \\
\text { технічної бази }\end{array}$ & $\begin{array}{l}\text { - запровадження } \\
\text { Інтернет-систем } \\
\text { управління } \\
\text { відносинами зі } \\
\text { споживачами; } \\
\text { - запровадження } \\
\text { практики } \\
\text { використання ІКТ } \\
\text { для впровадження } \\
\text { діджиталізації } \\
\text { комерційних } \\
\text { процесів; } \\
\text { - проведення } \\
\text { заходів для } \\
\text { збільшення } \\
\text { обсягів продажу } \\
\text { інноваційних } \\
\text { товарів; } \\
\text {-позиціонування } \\
\text { інноваційної } \\
\text { продукції }\end{array}$ & $\begin{array}{l}\text { - матеріальна та } \\
\text { нематеріальна } \\
\text { мотивація } \\
\text { персоналу за } \\
\text { інноваційні } \\
\text { розробки, } \\
\text { інвестиційні } \\
\text { пропозиції, } \\
\text { підвищення } \\
\text { ефективності } \\
\text { діяльності; } \\
\text { - реалізація } \\
\text { соціально- } \\
\text { економічних } \\
\text { програм розвитку } \\
\text { інтелектуальної } \\
\text { творчої та } \\
\text { інноваційної } \\
\text { діяльності } \\
\text { персоналу; } \\
\text { - забезпечення } \\
\text { комерціалізації } \\
\text { та правової } \\
\text { захищеності } \\
\text { об`єтів права } \\
\text { інтелектуальної } \\
\text { власності }\end{array}$ \\
\hline
\end{tabular}

Джерело: вдосконалено на основі [11]

ного забезпечення підприємства. Тобто підприємствам галузі потрібні технології, які зможуть у короткий часовий відрізок забезпечити окупність вкладених інвестицій та диверсифікувати діяльність. Необхідним є спрямування діяльності на розроблення і реалізацію нових фінансово-інвестиційних інструментів, а також на пошук нових підходів до впровадження інновацій через їх застосування [4].

Інноваційний розвиток потребує впорядкування комерційно-збутового механізму підприємства на основі інформаційно-аналітичних засобів та маркетингово-логістичних і техніко-технологічних систем. Підприємствам необхідно враху- вати розвиток інформаційних технологій, пошуку нових джерел постачання товарів і способів їх подальшого руху до споживача для активізації інноваційного розвитку.

Виробничо-технологічний механізм зосереджує процеси впровадження і використання новітніх технологій, модернізацію матеріальнотехнічної бази та формування ефективного ресурсного потенціалу. Метою впровадження даного механізму є загальна і системна модернізація виробничої бази, вдосконалення процесу впровадження інновацій.

Ефективність розвитку залежить від мотиваційних механізмів та їхніх складників. Застосу- 
вання соціально-мотиваційного механізму передбачає впровадження інновацій із найбільшим соціальним результатом. Основне призначення такого механізму - мотивувати персонал підприємства на інноваційний напрям, культивувати розуміння персоналом безальтернативності інноваційного шляху розвитку, комплексне впровадження інноваційних розробок.

Використання вказаних механізмів дасть змогу набути додаткових конкурентних переваг суб' єктами господарювання, залучити нові джерела інвестиційних ресурсів та забезпечити ефективне їх використання, активізувати зовнішні програми інвестиційно-інноваційного співробітництва, забезпечити підгрунтя для створення кластерів та інших сучасних форм об'єднань для інноваційного розвитку підприємств.

Висновки. Уважаємо, що для досягнення мети щодо формування та реалізації механізмів забезпечення інноваційного розвитку агропромислових підприємств необхідне застосування організаційно-інституційного, економічного виробничо-технологічного, комерційно-збутового, соціально-мотиваційного інструментів: в організаційно-інституційному - правове забезпечення; стратегічне і тактичне планування; інформаційно-аналітичної підтримки; «портфельний підхід» до бюджетування інновацій; участь в інноваційних кластерах та мережевих структурах; в економічному - інвестування коштів у розширення і модернізацію; використання альтернативних джерел фінансування; у виробничо-технологічному - розширення асортименту інноваційних товарів; диверсифікація; проведення модернізації технологічного процесу; розширене відтворення та технічне оновлення матеріально-технічної бази; у комерційно-збутовому - запровадження Інтернет-систем управління відносинами зі споживачами; використання ІКТ для діджиталізації комерційних процесів; у соціально-мотиваційному - мотивація персоналу за інноваційні розробки; соціально-економічні програми розвитку інтелектуальної, творчої та інноваційної діяльності персоналу з метою підвищення ефективності фінансово-інвестиційного забезпечення інноваційного розвитку агропромислових підприємств.

\section{Список використаних джерел:}

1. Шумпетер Й. Теория экономического развития (Исследование предпринимательской прибыли, капитала, кредита, процента и цикла конъюнктуры) / пер. с англ. Москва : Прогресс, 1982. 455 с.

2. Ілляшенко С.М. Маркетинг. Менеджмент. Інновації : монографія / за ред. С.М. Ілляшенка. Суми : Папірус, 2010. $621 \mathrm{c}$.

3. Вініченко I.I. Інноваційна діяльність аграрних підприємств: стан та пріоритети. Бюлетень Міжнародного Нобелівського економічного форуму. 2012. № 1(1). С. 44-48.

4. Никифоренко В.Г., Кравченко В.О. Інноваційний розвиток підприємств у контексті технологічного оновлення економіки. Вісник соціально-економічних досліджень. 2013. Вип. 2(49). Ч. 1. С. 48-53.

5. Волощук К.Б. Механізми інноваційно-інвестиційного розвитку агропромислових підприємств. Кам'янецьПодільський : Сисин О.В., 2011. 320 с.

6. Тофанчук А.Т., Колесник М.В. Соціально-економічні особливості інноваційного процесу. Проблеми підвищення ефективності інфраструктури. 2010. Вип. 26. С. 61-68.

7. Шипуліна Ю.С., Ілляшенко С.М. Розвиток теоретико-методологічних засад переходу підприємств на інноваційний шлях розвитку. Маркетинг і менеджмент інновацій. 2011. Т. 1. № 4. С. 103-112.

8. Юрин С.В. Ресурсное обеспечение национальной инновационной системы. Креативная экономика. 2010. № 7(43). С. 28-33.

9. Шевчук Д.А. Корпоративные финансы. Москва : ГроссМедиа ; РОСБУХ, 2008. 421 с.

10. Балан О.Д. Удосконалення системи матеріального стимулювання в сільськогосподарських підприємствах : автореф. дис. ... канд. економ. наук : 08.02.01. Київ, 2006. 20 с.

11. Орлик І.О., Васильців Т.Г., Рудик С.А. Механізми та засоби активізації інноваційного розвитку підприємств роздрібної торгівлі. Вісник Хмельницьккого національного університету. 2016. № 1. С. 102-109.

\section{References:}

1. Shumpeter Y. (1982). Teoriya ekonomicheskogo razvitiya (Issledovanie predprinimatelskoy pribyili, kapitala, kredita, protsenta i tsikla konyunkturyi) [Theory of Economic Development (Study of Entrepreneurial Profit, Capital, Credit, Interest and Cycle)]. Moscow: : Progress. 455 p.

2. Illiashenko S. M. (2010). Marketynh. Menedzhment. Innovatsii : monohrafiia [Marketing. Management. Innovation: monograph]. Sumy : TOV «Torhovyi dim «Papirus». $621 \mathrm{p}$.

3. Vinichenko I. I. (2012). Innovatsiina diialnist ahrarnykh pidpryiemstv: stan ta priorytety [Innovative activity of agrarian enterprises: state and priorities]. Biuleten Mizhnarodnoho Nobelivskoho ekonomichnoho forumu. № 1 (1). pp. 44-48.

4. Nykyforenko V. H., Kravchenko V. O. (2013). Innovatsiinyi rozvytok pidpryiemstv u konteksti tekhnolohichnoho onovlennia ekonomiky [Innovative development of enterprises in the context of technological modernization of the economy. ed. Z.M. Shcherbak.]. Visnyk sotsialno-ekonomichnykh doslidzhen. Odeskyi natsionalnyi ekonomichnyi universytet; №. 2 (49). Part 1. pp. 48-53.

5. Voloshchuk K. B. (2011). Mekhanizmy innovatsiino-investytsiinoho rozvytku ahropromyslovykh pidpryiemstv [Mechanisms of innovation-investment development of agro-industrial enterprises]. Kamianets-Podilskyi : Sysyn O.V. 320 p. 
6. Tofanchuk A. T., Kolesnyk M. V. (2010) Sotsialno-ekonomichni osoblyvosti innovatsiinoho protsesu [Socio-economic features of the innovation process]. Problemy pidvyshchennia efektyvnosti infrastruktury: zb. nauk. prats (ekonomichni nauky). Kyiv : NAU. Vol. 26. pp. 61-68.

7. Shypulina Yu. S., Illiashenko S. M. (2011). Rozvytok teoretyko-metodolohichnykh zasad perekhodu pidpryiemstv na innovatsiinyi shliakh rozvytku [Development of theoretical and methodological foundations of transition of enterprises to the innovative way of development]. Marketynh i menedzhment innovatsii. T. 1, No. 4. P. 103-112.

8. Iuryn S.V. (2010). Resursnoe obespechenie natsionalnoy innovatsionnoy sistemyi [Resource provision of the national innovation system]. Kreativnaya ekonomika. N o. 7 (43). Pp. 28-33.

9. Shevchuk D.A. (2008). Korporativnyie finansyi [Corporate Finance]. Moscow: : HrossMedya: ROSBUKh, 421 p.

10. Balan O.D. (2006). Udoskonalennia systemy materialnoho stymuliuvannia $\mathrm{v}$ silskohospodarskykh pidpryiemstvakh [Improvement of the system of material incentives in agricultural enterprises] : avtoref. dys. ... kand. ekonom. nauk : 08.02 .01 . Kyiv. 20 p.

11. Orlyk I. O., Vasyltsiv T. H., Rudyk C. A. (2016). Mekhanizmy ta zasoby aktyvizatsii innovatsiinoho rozvytku pidpryiemstv rozdribnoi torhivli [Mechanisms and means of activation of innovative development of retail trade enterprises]. Visnyk Khmelnytskoho natsionalnoho universytetu. No. 1. pp. 102-109.

Voloshchuk Vitaliy, Bohachyk Sergiy

State Agrarian and Engineering University in Podilya

\section{MECHANISMS OF PROVIDING INNOVATIVE DEVELOPMENT OF AGRICULTURAL ENTERPRISES}

In the domestic enterprises of agricultural sphere the effective use of mechanisms and means of activation of innovative development is conditioned by peculiarities in the issues of financial and investment opportunities, production process, technologies, regulatory and legal support, intellectual property, implementation process, etc. The research methodology is based on theoretical developments and scientific tools, including methods of dynamic series construction, comparative and economic analysis, it allows to systematize and determine tendencies of investment support of innovative development. The source of the research data is the data on investment processes in the agricultural sector in the Khmelnytskyi oblast, which were published by the General Directorate of Statistics in the Khmelnytskyi oblast, taking into account the period of 2010-2018. The purpose of the article is to define and substantiate the mechanisms and tools for activating innovative development of agro-industrial enterprises. The necessity of reproduction of agroindustrial enterprises by means of innovative development is substantiated. The constituent mechanisms of the system of activation of innovative development and the tools for providing innovative development of enterprises in general and its structural elements in particular are determined. The state of financing of innovative development of the region is analyzed and directions for activation of this type of development are defined. The necessity of introduction of such mechanisms of activation of innovative development of agro-industrial enterprises, such as organizationalinstitutional, economic, production and technological, commercial and marketing, and social-motivational, is substantiated. The tools, ensuring the positive effect of these mechanisms, are outlined. It is determined that the innovative development of agro-industrial enterprises entails high investment risks. The use of these mechanisms will allow to gain additional competitive advantages for economic entities, attract new sources of investment resources, and ensure their effective use, activate external programs of investment and innovation cooperation, provide a basis for creating clusters and other modern forms of associations for innovative development of enterprises.

Key words: innovations, development, resources, agricultural enterprise, financing, investments.

JEL classification: G31, O13, O32. 